Received $\quad 07.08 .2018$

Reviewed 22.10.2018

Accepted 29.11.2018

A - study design

B - data collection

C - statistical analysis

D - data interpretation

$\mathbf{E}$ - manuscript preparation

F - literature search

\section{Age structure, condition and length increase of the topmouth gudgeon (Pseudorasbora parva Schlegel 1842) in non-native populations of small rivers of Poland}

\author{
Przemysław CZERNIEJEWSKI ${ }^{1)}$ ABCDEF , Kinga ZATOŃ ${ }^{2)}$ ABCDEF, \\ Natalia KASOWSKA ${ }^{3) \text { ABCDEF }}$, Adam BRYSIEWICZ ${ }^{4) A B C D E F ~} ه$
}

1) orcid.org/0000-0001-8553-9109; West Pomeranian University of Technology in Szczecin, Faculty of Food Sciences and Fisheries, Szczecin, Poland; e-mail: przemyslaw.czerniejewski@zut.edu.pl

2) orcid.org/0000-0003-2773-5392; West Pomeranian University of Technology in Szczecin, Faculty of Food Sciences and Fisheries, Szczecin, Poland; e-mail: kinga.zaton@zut.edu.pl

3) orcid.org/0000-0003-0323-0189; West Pomeranian University of Technology in Szczecin, Faculty of Food Sciences and Fisheries, Szczecin, Poland; e-mail: natalia.kasowska@zut.edu.pl

4) orcid.org/0000-0002-3032-7843; Institute of Technology and Life Sciences, al. Hrabska 3, 05-090 Raszyn, Poland; e-mail: a.brysiewicz@itp.edu.pl

For citation: Czerniejewski P., Zatoń K., Kasowska N., Brysiewicz A. 2019. Age structure, condition and length increase of the topmouth gudgeon (Pseudorasbora parva Schlegel 1842) in non-native populations of small rivers of Poland. Journal of Water and Land Development. No. 40 (I-III) p. 113-118. DOI: 10.2478/jwld-2019-0012.

\begin{abstract}
Monitoring studies of ichthyofauna, in particular non-indigenous species, are an important element of research on aquatic ecosystems. This information is essential for modelling population growth and predicting rates of expansion, quantifying ecological impacts and assessing the efficacy of removal and control strategies. Actually, the most compelling fish invasion in Polish freshwaters is arguably the accidental introduction of the topmouth gudgeon (Pseudorasbora parva). Age and lengths structure, condition factor and growth rate of the invasive populations of the topmouth gudgeon from small Polish rivers was examined. The samples were collected from the rivers: Molnica $(n=41)$, Myśla $(n=21)$ and Wardynka $(n=101)$ soon after the invasion was recorded (2017). Estimated ages of topmouth gudgeon ranged from $1+$ to 3+ for the Myśla River, from 1+ do 4+ for the Molnica River, and from 1+ to 5+ for the Wardynka River. The fish from the Molnica River was characterised by the lowest total and standard length (TL, SL), weight, and highest condition. The results of back-calculations and the parameters of von Bertalanffy's growth equation revealed distinct disproportions in the standard length $(\mathrm{mm})$ in individual age groups (Molnica River: $\mathrm{Lt}=54.94\left[1-\mathrm{e}^{-0.68885(1-0.003404)}\right]$, Myśla River: Lt $=55.39$ $\left[1-\mathrm{e}^{-0.74921(1-0.030962)}\right]$, Wardynka River: $\left.\mathrm{Lt}=66.33\left[1-\mathrm{e}^{-0.69348(1-0.369505)}\right]\right)$. The introduction of the topmouth gudgeon occurred in the upper and medium sectors of small rivers, but in subsequent years the species migrated to new sites further downstream and this may have affected the native ichthyofauna.
\end{abstract}

Key words: fish, fish age, fish condition, fish growth, invasive species, Pseudorasbora parva, small river

\section{INTRODUCTION}

One of the unfavourable phenomenon affecting domestic species are invasions of expansive alien animals. The newly introduced species, by increasing their range, may pose a serious ecological and economic threat [AN-
DERSEN et al. 2004]. They cause changes in the ecological structure of the habitats of native species [MCKINNEY, LOCKWOOD 1999] and negatively affect the density and biodiversity within the ecosystem [CZERNIEJEWSKI, BRYSIEWICZ 2018]. One of the representatives of these species is the topmouth gudgeon (Pseudorasbora parva Schlegel 
1842), considered as one of the most invasive fish in Europe [BRITTON et al. 2007]. This cyprinus fish comes from eastern Asia, where it occurs in the waters of Japan, China, Korea and the Amur River basin [KOSTRZEWA et al. 2004]. It was accidentally introduced into Europe in 1961, together with carp stocking material for breeding ponds in the Danube River delta on the Romanian side [BĂNĂRESCU 1999]. Since then, the topmouth gudgeon penetrated, along with the stocking material from ponds to the natural waters of Germany, Albania and Lithuania [HOLČIK 1991], as well as to Israel [WelCOMME 1981]. At the end of the 1970s this species was recorded in France [Allardi, Chancerel 1988], and in the 80s in Poland [WITKOWSKI 1991]. The success of their fast settling of new areas should(can?) be explained by the development of international logistics in aquacul-

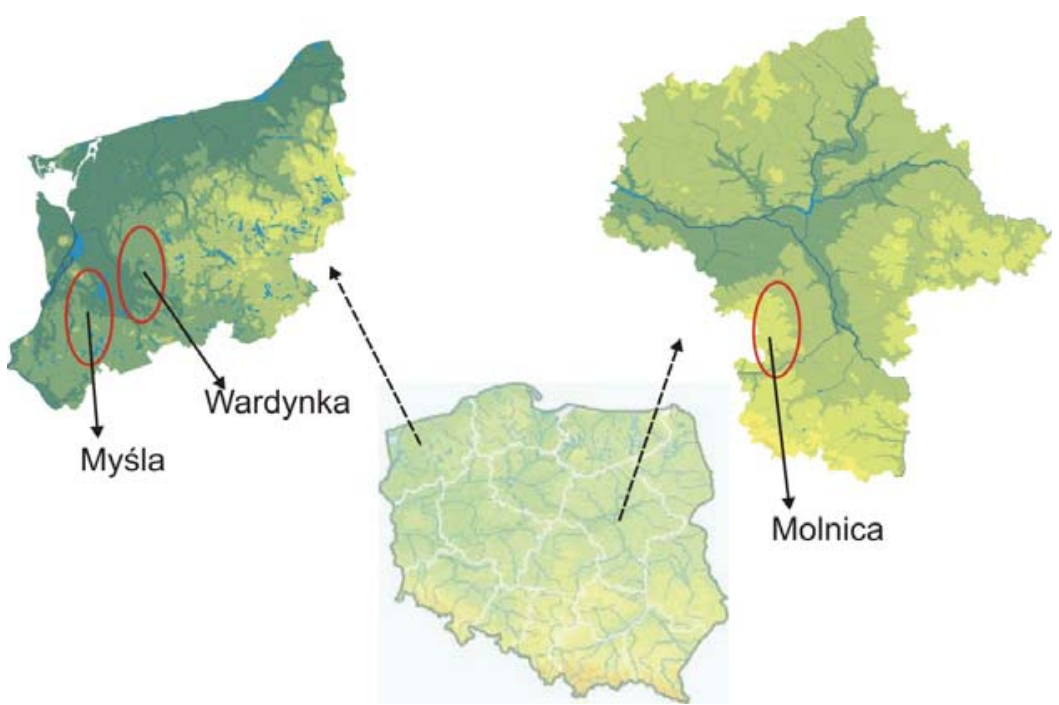

Fig. 1. Localisation of the rivers Molnica, Myśla and Wardynka; source: own elaboration ture, but also by biological features that enable its survival in new conditions [ARKUSH et. al. 2003]. The dynamic spreading of the topmouth gudgeon is one of the themes of previous scientific work [EKMEKÇI, KIRANKAYA 2006; GOZLAN et al. 2010; WITKOWSKI 2009]. Much less interest was devoted to population structures of this species in small rivers. However, continuous biological monitoring of the topmouth gudgeon's population should be important in assessing the risk of invasive species spreading and reducing costs associated with adverse changes in the environment related with its occurrence [BRITTON et al. 2007].

The aim of this study was (1) to assess the population condition and structure of the invasive topmouth gudgeon in the small streams of the Odra and Vistula basins (Poland) and (2) to determine its potential impact on native fish species and their habitats in the light of possible migration and colonisation.

\section{MATERIAL AND METHODS}

Fishing was carried out with the aid of an approved electric generator (ELT 60 II GI) from June 12th to August 30th 2017 at previously designated sites in three streams located in the Vistula River basin - the Molnica River (in the central part of Poland) and the Odra River basin - the rivers: Myśla and Wardynka (in the northwestern part of Poland) - Figure 1

Fishing was carried out by wading in every stream on $100 \mathrm{~m}$ long sections. The entire width of the river bed was fished. Altogether 160 fish of this species were collected. After fishing, the topmouth gudgeon were transported in ice to the laboratory of the Fisheries Management and Water Protection Department, West Pomeranian University of Technology in Szczecin for further analysis, while the remaining caught species were re-introduced to the trapping sites.

In the laboratory, the fish were measured from the end of the fish mouth to the end of the longer flap of the caudal fin $(T L)$ and from the tip of the fish mouth to the back edge of the last vertebra (body length $-S L$ ) to the nearest
$0.1 \mathrm{~mm}$ and weighed on the electronic type AXIS (accurate to $0.1 \mathrm{~g}$ ). In addition, on the basis of Fulton's coefficient $\left(\mathrm{KF}=\mathrm{W} \cdot \mathrm{SL}^{-3} \cdot 100\right)$, the condition of the fish was assessed [RITTERBUSCH-NAUWERCK 1995].

Basic water quality measurements like temperature, $\mathrm{pH}$ of the water and the dissolved oxygen content were carried out by using a $\mathrm{HACH}$ multi-parameter portable meter (HQ40D) and measured directly in the field. At the same time, $1 \mathrm{dm}^{3}$ of water samples were collected and measured for nitrates, ammonium and orthophosphates in the laboratory with a colourimetric HACH DR890 meter. In the study, a single measurement of water in rivers was made and the obtained results determine basic hydrochemical data and nutrient content in small rivers where topmouth gudgeon was found. Six scales were removed from between the lateral line and dorsal fin of each specimen. Scales were cleaned by alkaline immersion method [HUANG et al. 2015] and compressed between two glass slides for age determination by counting the number of completely developed annual rings [ROSECCHI et al. 1993]. The hardware set such as PC, an Eclipse E600 stereomicroscope with integrated Nikon's HD camera and Lucia image analysis program were used to measure the caudal diameter scale and annual increments. Growth in previous years was determined by back calculation from scale measurements following the R. Lee method [ZÁHORSKÁ et al. 2010].

The measurement results were analysed statistically, calculating e.g. the mean value $(\bar{x})$, standard deviation $(S D)$, ranges, using STATISTICA 12.0 PL (StatSoft, Poland). In the case of comparisons of mean values between populations, a one-way variance analysis (ANOVA) was used. Distribution normality in each group was checked using the Shapiro-Wilk test whereas the equality of variance was assessed using Levene's test. Tukey's HSD test was used as a post hoc test. In order to compare means between the sexes, the Student $t$-test was used, following testing the normality of distributions of the variables, using the Kolmogorov-Smirnov test [SOKAL, ROHLF 2012]. 
Table 1. Mean and standard deviations $(S D)$ of lengths, weight and condition of the topmouth gudgeon populations collected from small Polish rivers

\begin{tabular}{|c|c|c|c|c|c|c|}
\hline \multirow[t]{2}{*}{ River } & \multirow[t]{2}{*}{ Sex } & \multirow{2}{*}{$\begin{array}{c}\text { Number } \\
\text { of individuals }\end{array}$} & $\begin{array}{c}\text { Total length } \\
(\mathrm{mm})\end{array}$ & $\begin{array}{l}\text { Standard length } \\
(\mathrm{mm})\end{array}$ & $\begin{array}{l}\text { Weight } \\
(\mathrm{g})\end{array}$ & Fulton's coefficient \\
\hline & & & \multicolumn{4}{|c|}{ mean $\pm S D$} \\
\hline \multirow{3}{*}{ Molnica } & 우 & 23 & $43.74 \pm 8.41$ & $35.84 \pm 7.67$ & $1.12 * \pm 0.60$ & $0.23 \pm 0.09$ \\
\hline & $\hat{\sigma}$ & 18 & $40.56 \pm 9.66$ & $32.94 \pm 7.50$ & $0.74 * \pm 0.60$ & $0.19 \pm 0.06$ \\
\hline & total & 41 & $40.66^{\mathrm{a}} \pm 9.26$ & $33.22^{\mathrm{a}} \pm 7.73$ & $0.85^{\mathrm{a}} \pm 0.60$ & $0.21^{\mathrm{a}} \pm 0.05$ \\
\hline \multirow{3}{*}{ Myśla } & q & 7 & $51.57 \pm 5.65$ & $42.14 \pm 4.22$ & $0.97 \pm 0.18$ & $0.13 \pm 0.03$ \\
\hline & $\hat{3}$ & 11 & $54.27 \pm 4.05$ & $44.27 \pm 3.35$ & $1.18 \pm 0.33$ & $0.13 \pm 0.02$ \\
\hline & total & 18 & $53.22^{\mathrm{b}} \pm 4.77$ & $43.44^{\mathrm{b}} \pm 3.75$ & $1.10^{\mathrm{ab}} \pm 0.30$ & $0.13^{\mathrm{b}} \pm 0.02$ \\
\hline \multirow{3}{*}{ Wardynka } & 우 & 51 & $49.41 * \pm 10.11$ & $40.55 * \pm 8.39$ & $1.30 * \pm 0.97$ & $0.16 \pm 0.04$ \\
\hline & $\pi$ & 50 & $58.60 * \pm 14.40$ & $48.94 * \pm 12.15$ & $2.53 * \pm 2.04$ & $0.17 \pm 0.03$ \\
\hline & total & 101 & $53.96^{\mathrm{b}} \pm 13.19$ & $44.70^{\mathrm{b}} \pm 11.19$ & $1.91^{\mathrm{b}} \pm 1.70$ & $0.17^{\mathrm{b}} \pm 0.04$ \\
\hline
\end{tabular}

Explanation: values marked with the same letter do not differ statistically (ANOVA, $p<0.05$ ).

* differences statistically significant between females and males (test $t, p<0.05$ ).

Source: own results.

\section{RESULTS}

\section{THE STRUCTURE OF SEX, LENGTH, WEIGHT AND AGE OF FISHES}

The fish from the Molnica River were statistically significantly smaller in length $(T L, S L)$, unit weight $(W)$ and higher Fulton factor value in comparison to individuals caught in the other streams (Tab. 1). Sex ratio of fishes from all streams was 1:1, however, there were clear disproportions in the participation of males and females in individual streams. Males slightly prevailed only in the Myśla River (61.11\%), while females were slightly more in the other streams (Tab. 1). Among 160 individuals obtained in total from individual rivers, as many as $51.7 \%$ (75 individuals) were fishes aged $1+$ (Fig. 2). It should be emphasised that their share in the Wardynka River was over $67 \%$. However, in the Myśla and Molnica Rivers, despite the large share of fishes in the $1+$ age $(35.50 \%$ and $31.25 \%$ respectively), compared to the Wardynka River, there was a dominance of topmouth gudgeon in the age of $2+(61.3 \%$ and $62.5 \%$ respectively $)$. The low abundance of age group $3+$ and absence of fish from groups $4+$ and $5+$ in Myśla River can be explained by the fact that the topmouth gudgeon populations was not recorded in the Myśla River in earlier years and probably appeared only three years ago.

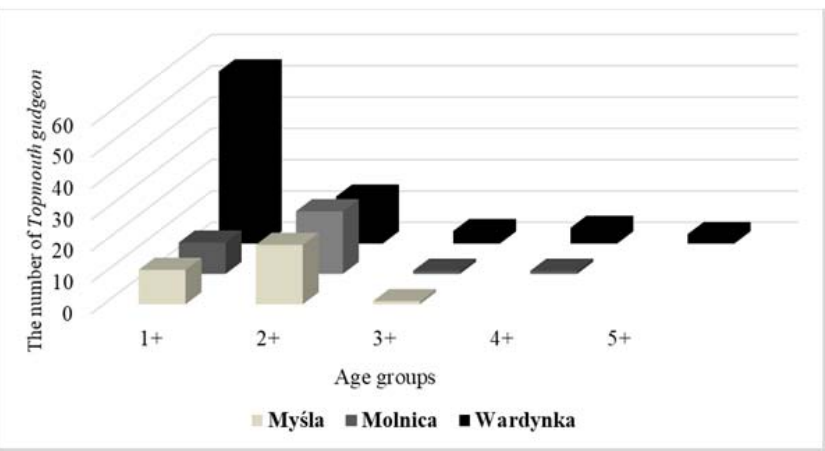

Fig. 2. Age structure of the topmouth gudgeon from some small Polish rivers; source: own results

\section{THE RATE OF FISH LENGTH INCREASE}

The rate of topmouth gudgeon's length increases from each stream and was determined on the basis of back readings and summarised in Table 2. The fish in individual waters reached the highest growth rate in the first year of life (the mean range in the analysed streams was 27.15 $31.26 \mathrm{~mm}$ ), in the $2 \mathrm{nd}$ and 3 rd year the increments are 2-3 times smaller compared to the values of these parameters from the previous year. Among the populations inhabiting the Wardynka, Myśla and Molnica Rivers, the best increase in the first year of life was observed in the topmouth gudgeon from the Wardynka River, whose total length was about $10 \%$ higher compared to the fish from other rivers. However, these differences are not statistically significant $(p>0.05)$ - Table 2 .

The lengths calculated by the back-calculated method in the Rosa Lee variant was used to determine the mathematical parameters of the length increase model according to the von Bertalanffy's equation. These models are as follows:

- the Molnica River: $\mathrm{Lt}=54.94\left[1-\mathrm{e}^{-0.68885(1-0.003404)}\right]$,

- the Myśla River: Lt $=55.39\left[1-\mathrm{e}^{-0.74921(1-0.030962)}\right]$,

- the Wardynka River: Lt $=66.33\left[1-\mathrm{e}^{-0.69348(1-0.369505)}\right]$.

Table 2. Mean standard lengths $\pm S D$ ( $\mathrm{mm}$ ) in particular age groups of the topmouth gudgeon collected from small Polish rivers

\begin{tabular}{|l|c|c|c|c|c|c|}
\hline \multirow{2}{*}{ Site } & \multirow{2}{*}{$\begin{array}{c}\text { Number of } \\
\text { individuals }\end{array}$} & \multicolumn{6}{|c|}{ Age groups } \\
\cline { 3 - 7 } & \multirow{2}{*}{ Molnica } & $\mathrm{L}_{1}$ & $\mathrm{~L}_{2}$ & $\mathrm{~L}_{3}$ & $\mathrm{~L}_{4}$ & $\mathrm{~L}_{5}$ \\
\hline \multirow{2}{*}{ Myśla } & \multirow{2}{*}{18} & $\begin{array}{c}27.15 \\
\pm 4.26\end{array}$ & $\begin{array}{l}41.86 \\
\pm 4.86\end{array}$ & $\begin{array}{c}47.20 \\
\pm 4.72\end{array}$ & 51.61 & \\
& & \pm 4.17 & $\begin{array}{l}42.22 \\
\pm 4.26\end{array}$ & 49.52 & & \\
\hline \multirow{2}{*}{ Wardynka } & \multirow{2}{*}{101} & 31.26 & 43.89 & 52.26 & 60.34 & 64.21 \\
& & \pm 3.18 & \pm 4.13 & \pm 4.21 & \pm 5.18 & \pm 4.11 \\
\hline
\end{tabular}

Explanation: $S D=$ standard deviation

Source: own results.

\section{HYDRO-CHEMICAL ANALYSES OF STREAMS}

The basic hydro-chemical analyses carried out at designated sites in selected rivers showed a relatively low $\mathrm{pH}$ water. The lowest $\mathrm{pH}$ values were recorded in the Molnica 
River. In the same river the highest electrolytic conductivity was found at an average level of $761 \mu \mathrm{S} \cdot \mathrm{cm}^{-1}$. The highest nutrient values, especially $\mathrm{NO}_{3}-\mathrm{N}$, were recorded in the Myśla River (Tab. 3).

Table 3. Basic hydro-chemical parameters of tested streams (own data)

\begin{tabular}{|c|c|c|c|c|c|c|c|}
\hline \multirow{2}{*}{ River } & \multirow{2}{*}{$\begin{array}{c}\text { Tempera- } \\
\text { ture } \\
\left({ }^{\circ} \mathrm{C}\right)\end{array}$} & \multirow{2}{*}{$\mathrm{pH}$} & \multirow{2}{*}{$\begin{array}{l}\text { Conduc- } \\
\text { tivity } \\
\left(\mu \mathrm{S} \cdot \mathrm{cm}^{-1}\right)\end{array}$} & $\mathrm{O}_{2}$ & $\mathrm{NO}_{3}-\mathrm{N}$ & $\mathrm{NH}_{4}-\mathrm{N}$ & $\mathrm{PO}_{4}-\mathrm{P}$ \\
\hline & & & & \multicolumn{4}{|c|}{$\left(\mathrm{mg} \cdot \mathrm{dm}^{-3}\right)$} \\
\hline Molnica & 19.80 & 7.60 & 750 & 2.20 & 10.60 & 0.03 & 0.90 \\
\hline Myśla & 14.20 & 7.26 & 761 & 7.59 & 8.25 & 0.06 & 0.42 \\
\hline Wardynka & 15.86 & 7.59 & 687 & 3.09 & 4.41 & 0.09 & 0.64 \\
\hline
\end{tabular}

Source: own study.

\section{DISCUSSION}

The appearance of a non-native species is extremely difficult to evaluate for our resources of native ichthyofauna. One of a new invasive species, which is topmouth gudgeon, appeared in the rivers: Molnica, Myśla and Wardynka. Unfortunately, they slowly began to settle in more and more Polish water reservoirs [GRABOWSKA et al. 2008]. In most cases, topmouth gudgeon lives in ponds [ADAMEK, SUKOP 2000; KAPUSTA et al. 2008; WITKOWSKI 1991], but recently also settled in small streams. The topmouth gudgeon is characterised by high environmental tolerance [GOZLAN et al. 2010], what was evidenced by the physico-chemical conditions of the tested streams (Tab. 3). However, the low oxygen content, at high $\mathrm{NO}_{3}$ and $\mathrm{PO}_{4}$ ions in the Myśla River, was undoubtedly the factor that influenced the lowest condition of the fish from this stream. However, the values of mean length (TL and $S L$ ) and weight $(W)$ of fish caught in the tested rivers (Tab. 2) were similar to those obtained for other non-native populations inhabiting the waters of Europe given by KAPUSTA et al. [2008], and ZÁHORSKÁ and KOVÁČ [2009]; ZÁHORSKÁ et al. [2010] $\left(T L_{\max }=60-100 \mathrm{~mm}\right)$.

The topmouth gudgeon belongs to short-lived species, with a maximum age of $5+$ in populations [GOZLAN et al. 2010]. The effect of the life's shortness of this species is the growth in length typical for this group of fish. These fishes are characterised large increases of lengths in the first year of life and their decrease in subsequent years The average lengths achieved in the first year of life by the fish from the tested streams are $27.15-31.26 \mathrm{~mm}$ and are within the broad range given for this species $(26-76 \mathrm{~mm})$ [GoZLAN et al. 2010]. Small body lengths (SL) achieved in the first year of life by topmouth gudgeon from the tested small rivers are probably caused by unfavourable physicochemical conditions of these streams, and above all low oxygen content and high biogen content.

A large difference in length in the first and subsequent years of the topmouth gudgeon's life in various positions (own data, BRITTON et al. 2007; ZÁHORSKÁ et al. 2010]) results from the geographical position, mainly temperature and water quality [GOZLAN et al. 2010], population density [BRITTON et al. 2007] and hydrological conditions. For example, a large current velocity of water in the stream can cause loss of energy in order to properly maintain the fish in the water currents, and also quickly moves food, which makes feeding harder [SUNARDI, MANATUNGE 2007].

The maximum age of the topmouth gudgeon within populations tends to be 3 or 4 years old, although a maximum age of 5 years has been recorded [BRITTON et al. 2007; KAPUSTA et al. 2008; RoSECCHI et al. 1993; ZÁHORSKÁ et al. 2010]. In the studied populations, individuals of the ages of $1+$ and $2+$ dominated, the maximum age of $5+$ was noted in only 2 males in the Wardynka River. Females rarely exceed $50 \mathrm{~mm}$ in length, with males the dominant sex in length classes above this [BRITTON et al. 2007; GIURCA, ANGELESCU 1971]. It should be emphasised that despite the dominance of fish in the ages of $1+$ and 2+ in populations of the Myśla, Molnica and Wardynka Rivers, the majority of fish harvested has already reached sexual maturity [ZÁHORSKÁ, KOVÁČ 2009]. Therefore, taking into consideration the high fertility of this species [KATANO, MAEKAWA 1997; ZÁHORSKÁ, KOVÁČ 2009], it is expected that the population will increase in these small rivers. The spread of this invasive species is favoured by small body size, hiding lifestyle, broad food spectrum, reproductive capacity on differentiated substrate, care for eggs and high tolerance for adaptation to the new environment [GOZLAN et al. 2010].

Also, anglers who use the topmouth gudgeon as a live catfish for predatory fish unwittingly help it in further expansion. This alien species of fish can pose some danger toward ecological stability of the water and native species diversity. First of all, topmouth gudgeon may be connected with the inevitable transfer of new pathogens and parasites unknown in our climate zone. According to GOZLAN et al. [2010], the topmouth gudgeon is the carrier of an extremely dangerous infection (rosette - like agent) caused by Sphaerothecum destruens. This intercellular parasitic protozoan is particularly dangerous for European salmonid and cyprinid fish species, which leads to necrosis of hepatocytes and soft tissues. Additionally, CESCO and CRIVELLE [2001], reported that for the last few years topmouth gudgeon became a vector of anguilicolosis - a disease caused by decimating European eel flock, nematode Anguillicola crassus. The above-mentioned diseases transmitted by topmouth gudgeon, can cause bunt and in extreme situations decimation of native species. According to the data presented in Table 3, the topmouth gudgeon, by its strengths, understood as low sensitivity to water quality, has fast adaptive abilities to new water bodies. The rapid adaptation of this non-native species also promotes spawning and males' care of the eggs which was confirmed by GOZLAN et al. [2010] and KosTRZEWA et al. [2004].

Colonising the new areas of the topmouth gudgeon displaces the native rheophile species from the habitats once occupied by them [KRUK et al. 2003]. The presence and constantly increasing number of topmouth gudgeon also very negatively affects domestic limnophilic fish species. Not only because of the consumption of spawn and juvenile stages of cyprinidae, such as rudd (Scardinius erythrophthalmus), crucian carp (Carassius carassius), bitterling (Rhodeus sericeus), gudgeon (Gobio gobio), sunbleak (Leucaspius delineatus), but also because of the transmission of numerous infectious diseases [BĂNĂRESCU 
1999; GlurCA, ANGElescu 1971]. Topmouth gudgeon feeds itself very little with plant food, therefore, eating animal food competes with native species of fishes [KOZLOV 1974; XIE et al. 2001].

Because of the threat to rare and endangered fish species, the topmouth gudgeon is called the "international pest species" [GOZLAN et al. 2005; PINDER et al. 2005; WINFIELD, DURIE 2004]. Topmouth gudgeon as invasive species has a very large impact on our native fish fauna. During mass occurrence in ponds, it competes for food with fish by eating larger species of plankton crustaceans. Topmouth gudgeon also contributes to an increase in the amount of phytoplankton, thereby increasing water eutrophication. In higher densities it can also pose a huge danger to rare and endangered fish species.

\section{REFERENCES}

ADAMEK Z., SUKOP I. 2000. Vliv strevlicky vychodni (Pseudorasbora parva) na parametry rybnicniho prostredi [The impact of topmouth gudgeon (Pseudorasbora parva) populations upon pond environmental determinants]. Biodiverzita Ichtyofauny. ĆR 3 p. 37-43.

Allardi J., Chancerel F. 1988. Sur la pre'sence en France de Pseudorasbora parva (Schlegel, 1842) [Ichthyological note On the presence in France of Pseudorasbora parva (Schlegel, 1842)]. Bulletin Français De La Pêche et de La Pisciculture. No. 306 p. 35-37.

Andersen M.C., Adams H., Hope B., Powell M. 2004. Risk assessment for invasive species. Risk Analysis. Vol. 24 p. 787-793.

Arkush K.D., Mendoza L., AdKISOn M.A., Hedrick R.P. 2003. Observations on the life stages of Sphaerothecum destruens n. g., n. sp., a mesomycetozoean fish pathogen formerly referred to as the rosette agent. Journal of Eukaryotic Microbiology. Vol. 50(6) p. 430-438.

BĂNĂRESCU P. 1999. Pseudorasbora parva (Temmnick et Schlegel 1846). In. The freshwater fishes of Europe. Ed. P. Bănărescu. 5.1. Cyprinidae 2/1 p. 207-224. Aula Verlag. Wiesbaden. ISBN 9783891040447 pp. 427.

BRitTON J.R., DAVIES G.D., BRAZIER M. 2009. Towards the successful control of the invasive Pseudorasbora parva in the UK. Biological Invasions. Vol. 12(1) p. 125-131.

Britton J.R., Davies G.D., Brazier M. Pinder A.C. 2007. A case study on the population ecology of a topmouth gudgeon (Pseudorasbora parva) population in the UK and the implications for native fish communities. Aquatic ConservationMarine and Freshwater Ecosystems. Vol. 17 p. 749-759.

Cesco L A, CRIVElle A. J. 2001 Pseudoreasbora parva (Teleosteen, Cyprinidae) espece invasive, nouvel agent du maintien et de la dissemination de l'anguillicolose en France? Parasite, 8 p. $75-76$.

Czerniejewski P., Brysiewicz A. 2018. Condition and population structure of the round goby (Neogobius melanostomus Pallas, 1811) in Szczecin Lagoon in 2010-2014. Journal of Water and Land Development. No. 37 p. 49-55. DOI 10.2478/jwld-2018-0024.

EKMEKÇI F.G., KIRANKAYA S.G. 2006. Distribution of invasive fish species, Pseudorasbora parva (Temminck \& Schlegel, 1846) in Turkey. Turkish Journal of Zoology. Vol. 30(3) p. $329-334$

GluRCA R., ANGelescu N. 1971. Consideratii privinid biologia sia aria de raspindire geografica a cyprinidului. Pseudorasbora parva (Schlegel) in apele Romanei. Bulletin Cercetari Piscicole. Vol. 30 p. 99-109.
Gozlan R.E., Andreou D., Asaeda T., Beyer K., Bouhadad R., Burnard D., CAIOLA N., CAKIC P., DJiKANOVIC V., ESMAEILI H., Falka I., Golicher D., Harka A., Jeney G., Kovac W., Musil J., Nocita A., Povz M., Poulet N., Virbickas T., Wolter Ch., Tarkan A., Tricarico E., Trichkova T., VERREYCKEN H., WitKowsKi A., ZHANG H., ZWEIMUELleR I., BRITTON R. 2010. Pan-continental invasion of Pseudorasbora parva: towards a better understanding of freshwater fish invasions. Fish and Fisheries. Vol. 11 p. 315-340.

Gozlan R.E., St-Hilaire S., Feist S.W., Martin P., Kent M.L. 2005. Disease threat to European fish. Nature. No. 435 p. 1046.

GrabowsKa J., WitKowski A., KotUSz J. 2008. Inwazyjne gatunki ryb w polskich wodach - zagrożenie dla rodzimej ichtiofauny. W: Użytkownik rybacki - nowa rzeczywistość [Invasive species of fish in Polish waters - a threat to native ichthyofauna. In: Fishing user - a new reality]. Konferencja PZW. 19-21.03.2008 Spała). Warszawa. Wydaw. PZW p. $90-96$.

HoLČIK J. 1991. Fish introductions in Europe with particular reference to its central and eastern part. Canadian Journal of Fisheries and Aquatic Sciences. Vol. 48 (Suppl. 1) p. 13-23.

HuANG S., WANG Y., ZHeNG X., WANG W., CAO X. 2015. Comparative analysis of three methods of making scale specimens for small fish. Environmental Biology of Fishes. Vol. 98 p. $697-703$

Kapusta A., Bogacka-Kapusta E., CZarnecki B. 2008. The significance of stone moroko Pseudorasbora parva (Temminck and Schlegel) in the small-sized fish assemblages in the littoral zone of the heated Lake Lichenskie. Archives of Polish Fisheries. Vol. 16 p. 49-62.

Katano O., MaEKawa K. 1997. Reproductive regulation in the female Japanese minnow, Pseudorasbora parva (Cyprinidae). Environmental Biology of Fishes. Vol. 49 p. 197-205.

Kostrzewa J., GrabowsKi M., ZięBA G. 2004. Nowe inwazyjne gatunki ryb w wodach Polski [New invasive fish species in Polish waters]. Archives of Polish Fischeries. Vol. 12(2) p. 21-34.

Kozlov V.I. 1974. Amurskij čebačok - Pseudorasbora parva (Schl.) - novyj vid ichtiofauny bassejna Dnestra [Topmouth gudgeon - Pseudorasbora parva (Schl.) - the new species of ichtyofauna of the Dniester basin]. Vestnik Zoologii. No. 1 p. 77-78.

Kruk A., Kotusz J., SzymczaK M., Spychalski P. 2003. Czebaczek amurski Pseudorasbora parva (Schlegel, 1842) (Cyprinidae, Gobioninae) - nowy element w ichtiofaunie województwa łódzkiego [Topmouth gudgeon Pseudorasbora parva (Schlegel, 1842) (Cyprinidae, Gobioninae) - a new element in the ichthyofauna of the Lodz region]. Roczniki Naukowe Polskiego Związku Wędkarskiego. Nr 16 p. 97101.

MCKINNEY M.L., LOCKWOOD J.L. 1999. Biotic homogenization: A few winners replacing many losers in the next mass extinction. Trends in Ecology and Evolution. Vol. 14 p. 450 453.

Pinder A.C., Gozlan R.E., BritTon J.R. 2005. Dispersial of the invasive topmouth gudgeon Pseudorasbora parva in the UK: a vector for an emergent infectious disease. Fishery Management and Ecology. Vol. 12 p. 411-414.

RITTERBUSCH-NAUWERCK B. 1995. Condition or corpulence, fitness or fatness: A discusion of terms. Archiv für Hydrobiologie. Special Issues in Advanced Limnology. Vol. 46 p. $109-112$.

Rosecchi E., Crivelli A., Catsadorakis G. 1993. The establishment and impact of Pseudorasbora parva, an exotic fish species introduced into Lake Mikri Prespa (northwestern 
Greece). Aquatic Conservation: Marine and Freshwater EcoEcosystems. Vol. 3 p. 223-231.

SOKAL R.R., RoHLF F.J. 2012. Biometry: The principles and practice of statistics in biological research. 4th ed. New York. W. H. Freeman and Co. ISBN 0-7167-8604-4 pp. 937.

SunARdi A.T., MANATUNGe J. 2007. Physiological responses of topmouth gudgeon, Pseudorabora parva, to predator cues and variation of current velocity. Aquatic Ecology. Vol. 41 p. 111-118.

WelCOMME R.L. 1981. Register of international transfers of inland fish species. FAO Fisheries Technical Paper 213 pp. 120 .

WinfIELD I.J., DuRIE N.C. 2004. Fish introductions and their management in the English Lake District. Fishery Management and Ecology 11 p. 195-201.
WitKowski A. 1991. Pseudorasbora parva (Schlegel 1842) (Cyprinidae: Gobioninae) a new component of the Polish ichthyofauna. Przeglad Zoologiczny. Nr 35 p. 323-331.

WiTKOWSKI A. 2009. On the expansion and occurrence of an invasive species - Pseudorasbora parva (Temminck et Schlegel, 1846) (Teleostei: Cyprinidae: Gobioninae) in Poland. Fragmenta Faunistica 51(1) p. 25-32.

XIE S., CUI Y., Li Z. 2001. Dietary-morphological relationships of fishes in Liangzi Lake, China. Journal of Fish Biology. Vol. 58 p. $1714-1729$.

ZÁHORSKÁ E., KovÁČ V. 2009. Life history traits of invasive topmouth gudgeon Pseudorasbora parva from Slovakia. Journal of Applied Ichthyology. Vol. 25 p. 466-469.

ZÁHORSKÁ E., KovÁČ V., Katina S. 2010. Age and growth in a newly-established invasive population of topmouth gudgeon. Central European Journal of Biology. Vol. 5(2) p. 256261.

\section{Przemysław CZERNIEJEWSKI, Kinga ZATOŃ, Natalia KASOWSKA, Adam BRYSIEWICZ \\ Struktura wieku, kondycja i wzrost długości czebaczka amurskiego (Pseudorasbora parva Schlegel 1842) w nierodzimych populacjach w niewielkich ciekach w Polsce}

\section{STRESZCZENIE}

Badania monitoringowe ichtiofauny, w szczególności gatunków nierodzimych, są ważnym elementem badań nad ekosystemami wodnymi. Informacje te są niezbędne do modelowania wzrostu populacji i przewidywania tempa ekspansji, ilościowego określania skutków ekologicznych i oceny skuteczności strategii eliminacji tych ryb z wód rodzimych oraz ich kontroli. Jednym z najbardziej interesujących gatunków inwazyjnych w świecie ryb w polskich słodkowodnych wodach jest prawdopodobnie przypadkowe wprowadzenie czebaczka amurskiego (Pseudorasbora parva). W pracy analizowano strukturę wieku i długości, współczynnik kondycji i tempo wzrostu inwazyjnych populacji czebaczków amurskich z małych cieków w Polsce. Ryby złowiono w 2017 r. z rzek: Molnica $(n=41)$, Myśla $(n=21)$ i Wardynka $(n=101)$. Szacowany wiek czebaczków amurskich wynosił od 1+ do 3+ (Myśla), od 1+ do 4+ (Molnica) i od 1+ do 5+ (Wardynka). Ryby z Molnicy cechowały się najmniejszą długością całkowitą i długością ciała $(T L, S L)$ oraz masą osobniczą. Odczyty wsteczne i parametry równania wzrostu von Bertalanffy’ego ujawniły wyraźne dysproporcje w długości całkowitej w poszczególnych grupach wiekowych (rzeka Molnica: Lt $=54,94 \quad\left[1-\mathrm{e}^{-0,68885}\left(1_{-}{ }^{0,003404)}\right]\right.$, rzeka Myśla: $\mathrm{Lt}=55,39\left[1-\mathrm{e}^{-0,74921(1-0,030962)}\right]$, rzeka Wardynka: $\left.\mathrm{Lt}=66,33\left[1-\mathrm{e}^{-0,69348(1-0,369505)}\right]\right)$. Wprowadzenie czebaczka amurskiego miało miejsce w górnej i środkowej strefie małych cieków, ale w kolejnych latach gatunek ten może migrować do nowych miejsc zlokalizowanych w dolnych odcinkach rzek i może wpływać na rodzimą ichtiofaunę.

Słowa kluczowe: gatunki inwazyjne, kondycja ryb, Pseudorasbora parva, ryby, rzeki, wiek ryb, wzrost ryb 